\title{
Recombinant Derivatives of Bacillus subtilis Phage Z Containing the DNA Methyltransferase Genes of Related Methylation-proficient Phages
}

\author{
By P.-A. TERSCHÜREN, M. NOYER-WEIDNER AND T. A. TRAUTNER* \\ Max-Planck-Institut für molekulare Genetik, Ihnestrasse 73, D-1000 Berlin 33, Germany
}

(Received 8 September 1986; revised 4 November 1986)

\begin{abstract}
The DNA methyltransferase (Mtase) genes of temperate Bacillus subtilis phages SPR, $\phi 3 T$, SP $\beta$ and $\rho 11$ can be transferred by transfection and recombination to the genome of the related nonmodifying phage $\mathrm{Z}$. Integration of the Mtase genes occurs in phage Z DNA at a unique location which is homologous with the flanking regions of the Mtase genes of the related phages. In lysogenic cells carrying recombinant phages, expression of the Mtase genes is repressed, irrespective of whether the Mtase genes were derived from phage donors which were homo- or heteroimmune to phage $\mathrm{Z}$.
\end{abstract}

\section{INTRODUCTION}

The temperate Bacillus subtilis phages SPR, SP $\beta, \phi 3 \mathrm{~T}$ and $\rho 11$ code for DNA methyltransferases (Mtases) with multiple sequence specificity (Günthert \& Trautner, 1984). In non-modifying phage $Z$ (Hemphill et al., 1980), which also belongs to this group of related phages, the Mtase gene is deleted (Tran-Betcke et al., 1986). DNA fragments of SPR, $\phi 3 T$, SP $\beta$, and $\rho 11$ containing the Mtase gene as well as a DNA fragment of phage $Z$, which crosshybridized to such fragments, have been cloned (Kiss \& Baldauf, 1983; Noyer-Weidner et al., 1985). Sequence analysis (Tran-Betcke et al., 1986) revealed that all Mtase genes are flanked at their $3^{\prime}$ ends by a highly conserved region, while sequences at their $5^{\prime}$ ends are variable. Regions homologous to the 3' flank of all Mtase genes and to the $5^{\prime}$ flank of the SPR Mtase gene are also present in the genome of phage $Z$, where they form a contiguous DNA segment. We have shown that the Mtase genes of modification-proficient phages can be introduced by recombination into the phage $Z$ genome (Noyer-Weidner et al., 1983). In this study we investigate whether the integration of the Mtase genes occurs at random positions in the phage $\mathrm{Z}$ genome or specifically at the region which is homologous to sequences flanking the Mtase genes. Mtase-proficient phage $Z$ derivatives, containing the Mtase genes of phages heteroimmune to $Z$, have also been analysed for expression of the Mtase genes in the lysogenic state.

\section{METHODS}

Bacteriophages, strains and plasmids. Phages SPR, $\phi 3 \mathrm{~T}, \mathrm{SP} \beta, \rho 11$ and $\mathrm{Z}$ as well as recombinant phages (nomenclature see below) were purified and the DNA extracted as described by Noyer-Weidner et al. (1983). The nonlysogenic $\mathrm{r}^{-} \mathrm{m}^{-}$B. subtilis strain SB1 207 (Trautner et al., 1980) served as host for these phages. The Z-lysogenic derivative of strain CU1065 (Zahler et al., 1977) obtained by H. E. Hemphill was used as recipient strain in transfection experiments; the $\mathrm{r}^{+} \mathrm{m}^{+}$strain TB804 (Trautner et al., 1980) was used to select BsuR-resistant phages. Recombinant plasmids pBKU1 (Tran-Betcke et al., 1986), pSPR5 (=pSU2; Kiss \& Baldauf, 1983) and pBN16 (Noyer-Weidner et al., 1985) were used in DNA/DNA hybridization experiments. The cloned phage DNA fragments are shown in Fig. 1.

Recombination experiments. Competent cells of strain CU1065 lysogenic for non-modifying phage $\mathrm{Z}$ were

Abbreviations: AdoMet, $S$-adenosyl-L-methionine; MC, mitomycin C; Mtase, DNA methyltransferase; $r / m$, $B s u$ R restriction/modification genotype. 
(a)
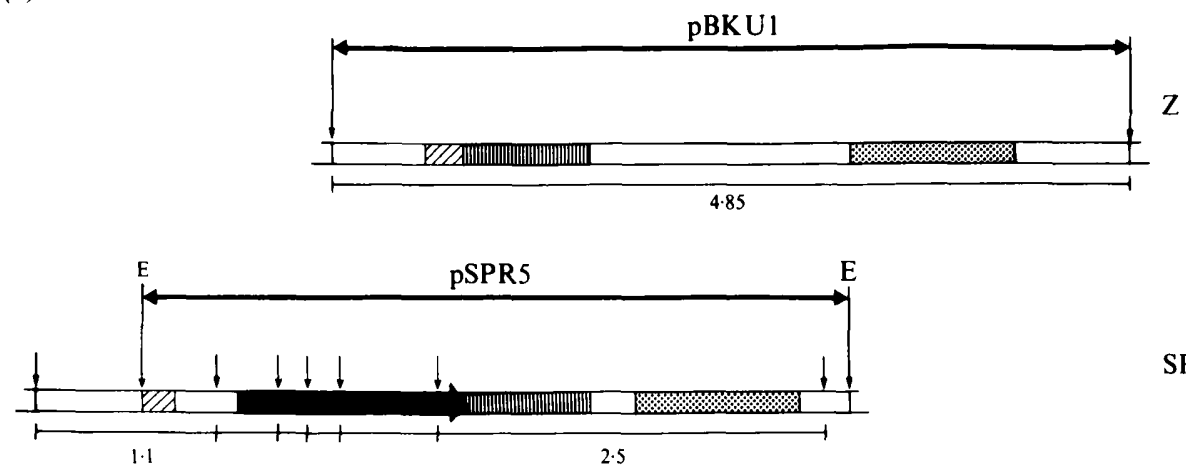

SPR

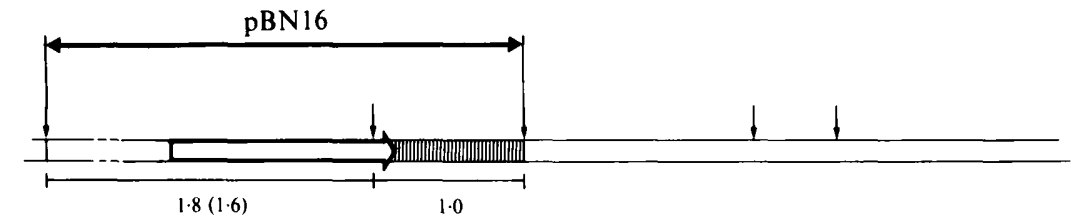

$\phi 3 \mathrm{~T}(\mathrm{SP} \beta, \rho 11)$

(b)

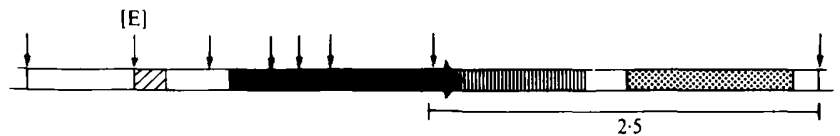

R/Z-E I
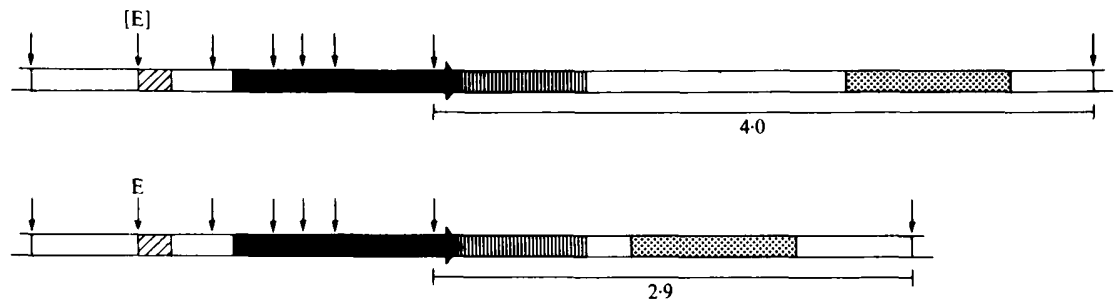

(c)
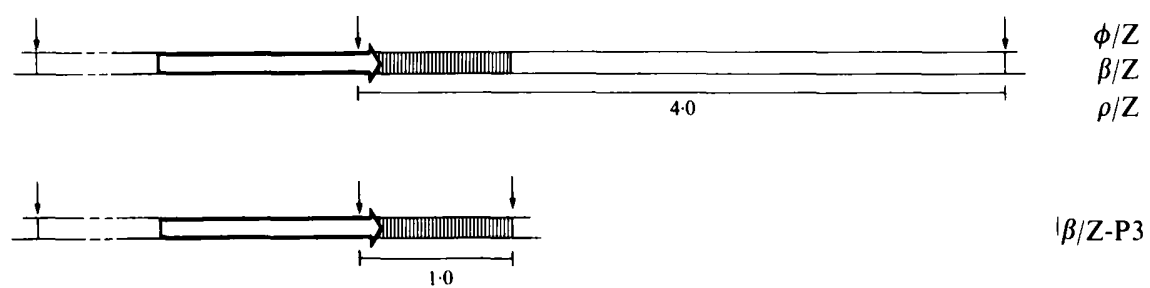

Fig. 1. Schematic representation of parental and recombinant genomes in the Mtase coding region. The Mtase genes and their direction of transcription are marked by a solid (SPR) or an open $(\phi 3 \mathrm{~T}=\mathrm{SP} \beta, \rho 11)$ arrow. Homologous regions outside the Mtase genes are marked identically. Nonhomologous regions are left blank. No information for the region $5^{\prime}$ of the EcoRI site of SPR DNA is available. Unless otherwise indicated, vertical arrows represent HindIII sites; E, EcoRI sites. The numbers give the size $(\mathrm{kb})$ of DNA fragments. (a) Genomes of recipient $(\mathrm{Z})$ and donor (SPR, $\phi 3 T, \operatorname{SP} \beta$, $\rho 11)$ phages. The extent of phage DNA contained in plasmid probes pBKU1, pSPR5 and pBN16 is marked with heavy double arrows. (b) Recombinants produced with SPR DNA. R/Z-B3 and R/Z-B4 do not contain the most leftward $E c o$ RI site from SPR. (c) Recombinants produced with $\phi 3 T, S P \beta$ and $\rho 11$ DNAs. The configuration of DNA of $\beta / Z-P 3$ to the right of the $1 \mathrm{~kb}$ HindIII fragment could not be assessed with the DNA probes available. 
transfected with either uncleaved or in vitro-restricted DNA of heterologous Mtase-proficient phage. Transfected cells were plated on the indicator strain, TB804.

General techniques. Restriction enzymes were purchased from Boehringer and New England Biolabs and used according to the recommendations of the suppliers. For DNA/DNA hybridization the probes were labelled by nick-translation following the procedure of Rigby et al. (1977). DNA polymerase I was purchased from Boehringer, and $\left[\alpha^{-32} \mathrm{P}\right] \mathrm{GTP}\left(3000 \mathrm{Ci} \mathrm{mmol}^{-1}, 110 \mathrm{TBq} \mathrm{mmol}^{-1}\right)$ from Amersham. DNA fragments were separated in $1 \%(\mathrm{w} / \mathrm{v})$ agarose gels (Maniatis et al., 1982) and blotted on Genescreen membranes (New England Nuclear) according to the method of Southern (1975). Hybridization and washing of Genescreen membranes was done under stringent conditions $\left(60^{\circ} \mathrm{C}\right)$ as described by the suppliers.

Preparation of crude extracts. Lysogenic B. subtilis cells were propagated in TY medium at $37^{\circ} \mathrm{C}$. Two cultures of each strain to be analysed were grown in parallel. At a cell titre of about $2 \times 10^{8} \mathrm{ml}^{-1}$ one of the cultures was induced with mitomycin $\mathrm{C}(\mathrm{MC})\left(0.25 \mu \mathrm{g} \mathrm{ml}^{-1}\right)$. After further incubation for $60 \mathrm{~min}$ the cells were harvested and disrupted in a French press cell $\left(13000 \mathrm{lbf}_{\text {in }}^{-2} ; 90 \mathrm{MPa}\right)$. The crude extracts were clarified by centrifugation at $50000 \mathrm{~g}$ for $40 \mathrm{~min}$ followed by dialysis against storage buffer containing $50 \%$ (v/v) glycerol (Günthert et al., 1981). The parallel culture was processed similarly without $\mathrm{MC}$ induction.

In vitro methylation assay. DNA methylation activity in crude extracts was determined as described previously (Günthert et al., 1981). Micrococcus luteus DNA (Serva) was used as substrate, and $S$-adenosyl[ $\left.{ }^{3} \mathrm{H}\right]$ methionine $\left(\left[{ }^{3} \mathrm{H}\right]\right.$ AdoMet ; $15 \mathrm{Ci} \mathrm{mmol}^{-1}, 550 \mathrm{GBq} \mathrm{mmol}^{-1}$; Amersham) as donor of methyl group. The Mtase unit is defined as the amount of enzyme that incorporates $1 \mathrm{pmol}$ of methyl groups from AdoMet into DNA in $1 \mathrm{~h}$ at $37^{\circ} \mathrm{C}$. Protein concentration in crude extracts were determined by the method of Lowry.

Nomenclature. In the designation of recombinant bacteriophages the first entry indicates the source of donor DNA $(R, \beta, \phi$ or $\rho)$, the second entry separated by a slash shows the name of the recipient phage $Z$. If recombinants are derived from in vitro-restricted DNA a symbol representing the enzyme used for restriction $(\mathrm{B}=\operatorname{BamHI}, \mathrm{E}=$ Eco RI, $\mathrm{P}=$ Pst $)$ follows the designation of the recombinant phage. Independently isolated phages derived from a single recombinant experiment are numbered sequentially. Example: R/Z-E2 is isolate number 2 of a methylation-proficient $Z$ derivative obtained by recombination with EcoRI-restricted SPR DNA.

\section{RESULTS}

\section{Characterization of modification-proficient phage $Z$ derivatives}

Competent cells of the Z-lysogenic $B$. subtilis strain CU1065 were transfected with either uncleaved or in vitro-restricted DNAs of phages SPR, $\phi 3$ T, SP $\beta$ and $\rho 11$ as previously described (Noyer-Weidner et al., 1983). For reasons unknown, such DNAs are biologically inactive in the transfection of non-lysogenic cells (Williams \& Young, 1977; Noyer-Weidner et al., 1983). To select for methylation-proficient phages, the transfected cells were plated on the $B s u R \mathrm{r}^{+} \mathrm{m}^{+}$ strain TB804. Table 1 shows that compared to uncleaved DNA, partial or total in vitro restriction of the donor DNA reduced or abolished its potential to generate BsuR-resistant phages, although none of the enzymes used cleaves within the Mtase genes (Noyer-Weidner et al., 1983, and authors' unpublished observations). This finding can be rationalized on the basis of the size of the Mtase-gene-carrying fragments (Table 1) and, in the case of $\phi 3 \mathrm{~T}$ and SPR, where mapping and/or sequencing data are available (Noyer-Weidner et al., 1985; Tran-Betcke et al., 1986), the location of the Mtase genes within these fragments. Phages obtained from singleplaque isolates proved to be recombinants since their resistance to $B s u R$ restriction was stably acquired.

The phages used in this study constitute two immunity groups, represented by phages SPR, $\operatorname{SP} \beta, Z$ and phages $\phi 3 \mathrm{~T}$ and $\rho 11$ (for a review see Zahler, 1982). While SPR, SP $\beta$ and Z form turbid plaques, $\phi 3 \mathrm{~T}$ and $\rho 11$ yield clear plaques, presumably due to a higher spontaneous phage induction rate (Noyer-Weidner et al., 1981). Transfection of CU1065(Z) with $\phi 3 T$ and $\rho 11$ DNAs yielded recombinant phages forming either turbid or clear plaques, which were homo- or heteroimmune respectively to $Z$. Immunity defined by this plaque morphology was verified by plating samples of phage lysates on $\mathrm{Z}$ or $\phi 3 \mathrm{~T}$ lysogenic strains.

The restriction patterns of DNAs from various independently isolated recombinants indicated that their DNA is either resistant to HaeIII and HpaII (donor phage SPR) or HaeIII and $F n u 4 \mathrm{HI}$ cleavage (donor phages $\phi 3 \mathrm{~T}, \mathrm{SP} \beta, \rho 11$ ) (Terschüren, 1985). Hence the recombinant phages express the complete modification potential of the donor phage. Further, the HindIII restriction patterns of Mtase-proficient SPR/Z recombinants (Fig. 2) differ markedly from the 


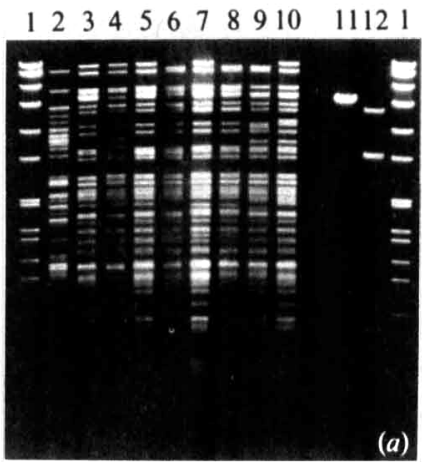

$234456789910 \quad 1112$

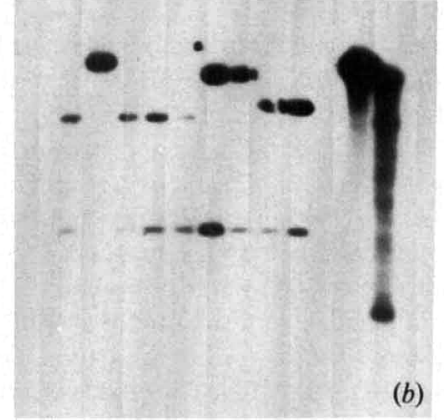

$\begin{array}{llllllllll}2 & 3 & 4 & 5 & 6 & 7 & 8 & 9 & 10 \quad 1112\end{array}$

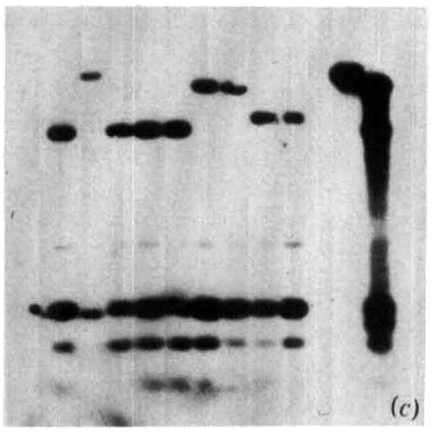

Fig. 2. Southern blot of representative recombinants. All phage and plasmid DNAs analysed were digested with HindIII. The digests were separated by gel electrophoresis $(a)$, transferred to Genescreen membranes and probed with nick-translated pBKUI $(b)$ and pSPR5 (c) DNAs. The tracks represent DNAs of : (1) molecular mass standard (EcoRI-degraded SPPI DNA: Ratcliff et al., 1979); (2) SPR; (3) Z; (4)-(10) recombinants R/Z-E1, -E2, -B3, -B4, -B5, -P6, -P7, respectively; (11) pBKU1; (12) pSPR5. In contrast to the $1.1 \mathrm{~kb}$ DNA fragment of SPR, a $0.46 \mathrm{~kb}$ DNA fragment of pSPR5 carries the homology region shared between sequences upstream of the Mtase gene and pBKUl. This is due to the presence of a HindIII site in the vector (pBR322) moiety located $30 \mathrm{bp}$ upstream of the leftmost EcoRI site confining the pSPR5 insert shown in Fig. $1(a)$.

Table 1. Generation of methylation-proficient phage $Z$ derivatives

Uncleaved $(0.75 \mu \mathrm{g})$ or in vitro-restricted $(4.5 \mu \mathrm{g})$ DNA was used for transfection. Recombination experiments (see Methods) were repeated once and the results resembled those presented. The sizes of the Mtase-carrying DNA fragments were previously determined by Kiss \& Baldauf (1983), NoyerWeidner et al. (1983) and M. Noyer-Weidner (unpublished).

\begin{tabular}{|c|c|c|c|}
\hline $\begin{array}{l}\text { Phage DNA used } \\
\text { for transfection } \\
\text { of CU1065(Z) }\end{array}$ & $\begin{array}{c}\text { Restriction } \\
\text { endonuclease } \\
\text { used for phage } \\
\text { DNA cleavage }\end{array}$ & $\begin{array}{l}\text { Approx. size of } \\
\text { the Mtase-carrying } \\
\text { DNA fragment } \\
\text { in cleaved DNA } \\
(\mathrm{kb})\end{array}$ & $\begin{array}{c}\text { No. of p.f.u. } \\
\text { obtained on } \\
\text { TB804 } \\
\left(B s u R \mathrm{r}^{+} \mathrm{m}^{+}\right)\end{array}$ \\
\hline SPR & $\begin{array}{l}\text { None } \\
\text { EcoRI* } \\
\text { BamHI } \\
\text { Pst } \mathrm{I}^{*}\end{array}$ & $\begin{array}{c}- \\
\quad 4 \cdot 3 \\
\text { ND }\end{array}$ & $\begin{array}{l}2.4 \times 10^{4} \\
2.7 \times 10^{2} \\
9.3 \times 10^{2} \\
4.5 \times 10^{1}\end{array}$ \\
\hline $\mathrm{SP} \beta$ & $\begin{array}{l}\text { None } \\
\text { EcoRI } \\
\text { PstI }\end{array}$ & $\begin{array}{l}- \\
12 \\
15\end{array}$ & $\begin{array}{l}3.9 \times 10^{3} \\
9.8 \times 10^{2} \\
5.0 \times 10^{2}\end{array}$ \\
\hline$\phi 3 \mathrm{~T}$ & $\begin{array}{l}\text { None } \\
\text { EcoRI } \\
\text { BglII } \\
\text { PstI }\end{array}$ & $\begin{array}{l}- \\
12 \\
4 \cdot 5 \\
14\end{array}$ & $\begin{array}{l}2.0 \times 10^{4} \\
1.5 \times 10^{3} \\
<10 \\
5.8 \times 10^{2}\end{array}$ \\
\hline$\rho 11$ & $\begin{array}{l}\text { None } \\
\text { EcoRI }\end{array}$ & - & $\begin{array}{l}1.2 \times 10^{4} \\
3.8 \times 10^{2}\end{array}$ \\
\hline
\end{tabular}

ND, Not determined.

- Partially digested DNA was used for transfection. Complete digests yielded no p.f.u. on TB804.

donor phage DNA patterns but resemble the pattern of phage Z DNA. Therefore only a limited amount of donor DNA was introduced into the $\mathrm{Z}$ genome in the generation of these phages. Restriction patterns of recombinant clones also differ from each other. Hence, different recombination events must have taken place in the generation of the various $S P R / Z$ recombinants. Analogous results were obtained by analysis of the HindIII restriction pattern of $\mathrm{SP} \beta / Z$ and $\phi 3 \mathrm{~T} / \mathrm{Z}$ or $\rho 11 / \mathrm{Z}$ phages forming turbid plaques (data not shown). 


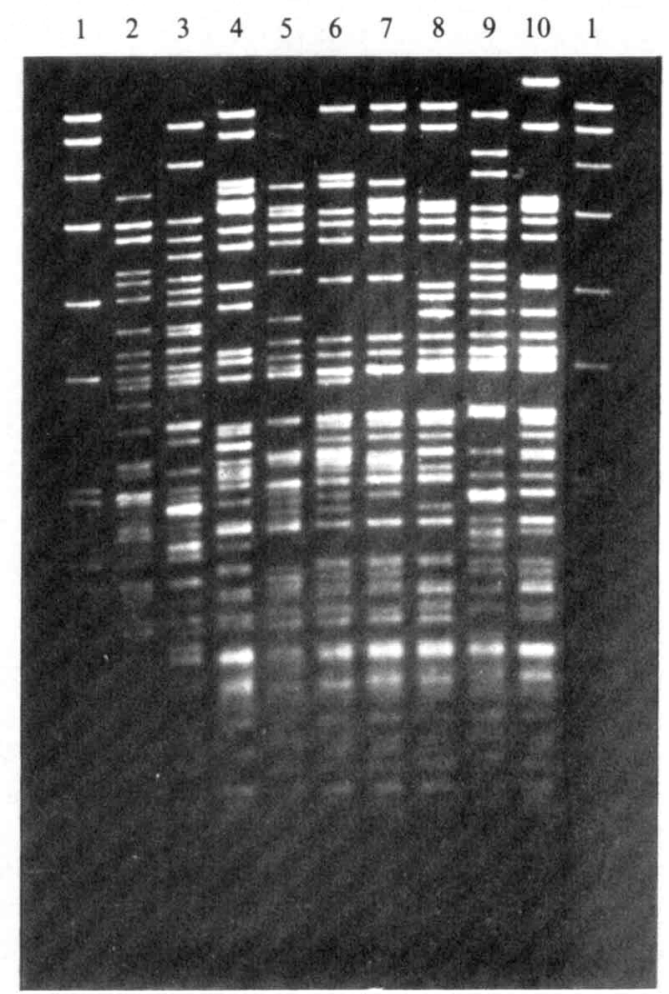

Fig. 3. HindIII restriction pattern of $\phi 3 \mathrm{~T}$ - and $\rho 1 \mathrm{l} / \mathrm{Z}$ Mtase-proficient phages with $\phi 3 \mathrm{~T} / \rho 11$ immunity. The tracks represent DNAs of: (1) molecular mass standard; (2) $\phi 3 \mathrm{~T}$; (3) $\rho 11$; (4) Z; (5)-(10) recombinants $\phi / Z-5,-6,-7,-8, \rho / Z-3,-4$, respectively.

The restriction patterns of Mtase-proficient $\phi 3 \mathrm{~T} / \mathrm{Z}$ and $\rho 11 / \mathrm{Z}$ phages forming clear plaques differ significantly from the restriction patterns of the donor and the recipient phage DNAs (Fig. 3) and among each other. Phages of this type must have been generated by multiple recombinational events between the donor and recipient DNAs, which also included genes affecting immunity.

\section{Localization of the Mtase genes within the recombinant phage genomes}

To localize the Mtase genes within the recombinant phage genomes, DNA/DNA hybridization experiments were done with two types of plasmid DNAs as probes.

(1) pBKU1 carries a $4.85 \mathrm{~kb}$ fragment of phage Z DNA comprising the sequences homologous to the flanks of the Mtase genes of the related phages (Fig. 1). Hybridization to pBKU1 reveals whether this fragment is conserved in the recombinant phages or has been affected by recombination. The latter would indicate specific integration of the Mtase genes into the homologous region of the phage $\mathrm{Z}$ genome.

(2) pSPR5 and pBN16 contain Mtase-coding DNA fragments of phages SPR and $\phi 3 T$ respectively. Hybridization to these plasmids proves the presence of the Mtase genes in the recombinant phages and reveals whether their immediate environment was involved in the recombination events. pBN16 was also used as a probe against SP $\beta / Z$ and $\rho 11 / Z$ DNAs since the Mtase-coding fragments of $\phi 3 \mathrm{~T}, \mathrm{SP} \beta$ and $\rho 11$ are extensively homologous (Noyer-Weidner et al., 1985).

Analysis of the results of the DNA/DNA hybridization experiments (Fig. 2), indicates that the unique restriction fragment of $Z$ DNA hybridizing with $\mathrm{pBKUl}$ is absent from all $S P R / Z$ recombinant DNAs. Instead, two new fragments give a hybridization signal. These fragments 
Table 2. Mtase activity in crude extracts of lysogenic SB1207 strains $\left(r^{-} m^{-}\right)$

Mtase activity and protein concentration were measured as described in Methods. Duplicate values were taken at two different concentrations of crude extracts; they varied by $10 \%$ or less. Mean results are presented.

\begin{tabular}{|c|c|c|}
\hline \multirow{3}{*}{$\begin{array}{l}\text { Prophage } \\
Z \\
\phi 3 T\end{array}$} & \multicolumn{2}{|c|}{$\begin{array}{l}\text { Specific Mtase activity } \\
\text { [units (mg protein) }{ }^{-1} \text { ] }\end{array}$} \\
\hline & $\begin{array}{l}\text { Uninduced } \\
69\end{array}$ & $\underset{65}{M C \text {-induced }}$ \\
\hline & 708 & 933 \\
\hline $\mathrm{R} / \mathrm{Z}-\mathrm{E} 2$ & 81 & 223 \\
\hline R/Z-B3 & 49 & 238 \\
\hline$\beta / Z-E 1$ & 64 & 172 \\
\hline$\beta / Z-P 3$ & 78 & 144 \\
\hline$\phi / Z-E 1$ & 52 & 239 \\
\hline$\phi / Z \cdot P 3$ & 65 & 366 \\
\hline$\rho / Z-E l$ & 78 & 252 \\
\hline
\end{tabular}

are among those which also hybridize against the SPR Mtase-coding DNA fragment contained in pSPR5. This hybridization pattern shows that the $\mathrm{Z}$ fragment containing the flanks of the SPR Mtase gene has become disrupted and associated with DNA of the Mtase genes. The Mtase genes of all SPR $/ Z$ recombinants are thus contained in a unique genomic location, which is defined by DNA homologous to the region of the SPR Mtase gene.

Within this general scheme, different hybridization patterns of individual recombinant clones were observed (Fig. 2). Differences in the DNA structure defining the flanks of the SPR Mtase gene or the corresponding fragment of Z DNA (Fig. 1) have permitted us to describe three types of recombination events affecting the $3^{\prime}$ flank of the SPR Mtase gene. These are represented by phages $\mathrm{R} / \mathrm{Z}-\mathrm{E} 1,-\mathrm{E} 2$, -B3; R/Z-B4, -B5; and R/Z-P6, -P7 (Fig. 1). Recombination at the $5^{\prime}$ end must have occurred in phages $R / Z-B 3,-B 4$ between the beginning of the gene and the 5'-proximal EcoRI site and in the other $\mathrm{R} / \mathrm{Z}$ phages at a location upstream of this site. This distinction was made by hybridization of pSPR5 against HindIII/EcoRI double digests of recombinant DNAs (not shown).

Analogous hybridization against $H$ indIII-cleaved $\phi 3 \mathrm{~T}-$, SP $\beta$ - and $\rho 11 / Z$ DNAs (Terschüren, 1985 , and unpublished) led to similar conclusions to those for the SPR/Z recombinants. In all the recombinant DNAs the $Z$ DNA fragment contained in pBKUl was absent, irrespective of whether they were derived from turbid or clear plaque-forming phages. This indicates that during generation of these recombinants the Mtase genes were integrated at the region of the $Z$ genome characterized by homology with their flanks.

Further analysis of the hybridization patterns of the DNA of turbid-plaque-forming recombinants (Terschüren, 1985) revealed that they are more homogeneous than the patterns of SPR $/ Z$ phages. In nine of the 10 recombinant DNAs analysed (four, three and two derived from recombinations between $Z$ and DNA of $\phi 3 T, S P \beta$ and $\rho 11$ respectively), recombination at the $3^{\prime}$ end must have occurred within the homologous sequences shared by $Z$ and the regions immediately downstream of the Mtase gene $(\phi / Z, \beta / Z$ and $\rho / Z$ in Fig. $1 c)$. The tenth recombinant, $\beta / Z$-P3, was generated by recombination at a location outside the probed DNA fragments (Fig. $1 c$ ). All $\phi 3 \mathrm{~T}$-, SP $\beta$ - and $\rho 11 / Z$ recombinants forming turbid plaques were generated by recombination events involving structures at the $5^{\prime}$ flank of the Mtase genes, which are located outside the region corresponding to the probed DNA fragments. This reflects the absence of homology between phage Z DNA and structures directly upstream of the $\phi 3 \mathrm{~T}, \mathrm{SP} \beta$, $\rho 11$ genes.

\section{Regulation of the Mtase gene expression in recombinant phage $Z$ derivatives}

The expression of the Mtase genes in Mtase-proficient phages is repressed in the lysogenic state (Noyer-Weidner et al., 1981; Jentsch, 1982). To investigate whether the same type of control operates in recombinant phages whose Mtase genes are derived from homoimmune or 
heteroimmune phages, we determined the Mtase activity in crude extracts prepared from either uninduced or MC-induced lysogenic strains (Table 2). The specific Mtase activities of extracts prepared from uninduced strains lysogenic for recombinant phages have background levels as defined by induced or non-induced $Z$ lysogens. The high level of Mtase activity found in extracts of uninduced $\phi 3 T$ lysogens is presumably caused by a rather high spontaneous induction rate of phage $\phi 3 \mathrm{~T}$ (Noyer-Weidner et al., 1981). In extracts prepared from MC-treated lysogens a significant increase of Mtase activity (2- to 6-fold in recombinant phage lysogens; 1-3-fold in $\phi 3 T$ lysogens) was found. These results demonstrate that in the recombinant phages heteroimmune to the donor phage the expression of the Mtase gene is repressed in the lysogenic state.

\section{DISCUSSION}

The results presented here show that in all Mtase-proficient phage $Z$ derivatives, the Mtase genes were integrated into a single region of the phage $Z$ genome, which carries sequences homologous to the flanks of the Mtase genes. The responsible double recombination event could involve various alternative homologous DNA sequences shared between $Z$ and regions immediately $3^{\prime}$ to the Mtase genes. While at least some of the SPR/Z recombinants were generated by recombination events affecting the immediate $5^{\prime}$ flank of the SPR Mtase gene, no recombination between $Z$ DNA and the immediate $5^{\prime}$ environment of the $\phi 3 T, \operatorname{SP} \beta$ and $\rho 11$ Mtase genes was detected. This reflects the differences in the relatedness of sequences preceding the various phage Mtase genes to phage Z DNA (Fig. 1).

Since DNA with the size of the Mtase genes (about $1.4 \mathrm{~kb}$ ) can be integrated into a specific region of the $Z$ genome without interfering with phage viability, this offers the possibility of constructing a $B$. subtilis cloning system based on phage $Z$. In a way similar to that described for temperate $B$. subtilis phage $\phi 105$ (Savva \& Mandelstam, 1984), foreign genetic material inserted into pBKUl or a derivative of this plasmid could be directed by recombination into the nonessential region of phage $Z$ defined by our experiments.

The Mtase genes of recombinant phages having $Z$ immunity are repressed in the lysogenic state, irrespective of whether they are derived from a phage homoimmune (SP $\beta, S P R$ ) or heteroimmune $(\phi 3 \mathrm{~T}, \rho 11)$ to phage $\mathrm{Z}$. The repressor defining phage immunity is therefore not directly involved in the repression of the Mtase genes. Most likely the Mtase gene forms part of a larger, phage-repressor-controlled, transcriptional unit that is directly repressed in the prophage state. It remains to be elucidated whether additional DNA structures involved in the control of Mtase gene expression are located on the DNA segments derived from the modificationproficient donor phages or are provided by DNA sequences of the recipient phage $Z$. Such an understanding requires an analysis of in vivo transcription.

Beyond our primary objective to localize the Mtase genes from various donor DNAs in the genome of recipient phage $Z$, we have recognized extensive recombination between donor and recipient DNA also in other areas of the $Z$ genome (Figs 2 and 3). Such recombination became genetically manifest in the exchange of genetic material determining the immunity of phages. In addition to this, we have observed an exchange of genes for antigenic determinants in transfections with DNA of phage SPR. Phage SPR represents a serotype distinct from that of the other phages studied here (Noyer-Weidner et al., 1983). Obviously extensive sequence homology exists between the various phage genomes in spite of significant polymorphism in restriction patterns. Analogous observations within the SPPI family of $B$. subtilis phages have recently been reported (Santos et al., 1986).

\section{REFERENCES}

GüNTHERT, U. \& Trautner, T. A. (1984). DNA methyltransferases of Bacillus subtilis and its bacteriophages. In Methylation of DNA (Current Topics in Microbiology and Immunology, vol. 108), pp. 11-22. Edited by T. A. Trautner. Berlin: Springer Verlag.
Günthert, U., Freund, M. \& Trautner, T. A. (1981). Restriction and modification in Bacillus subtilis: two DNA methyltransferases with BsuR specificity. Journal of Biological Chemistry 256, 93409345. 
Hemphill, H. E., Gage, I., Zahler, S. A. \& Korman, R. (1980). Prophage-mediated production of a bacteriocin-like substance by SP $\beta$ lysogens of Bacillus subtilis. Canadian Journal of Microbiology 26, 1328-1333.

JENTSCH, S. (1982). Restriktion und Modifikation in Bacillus subtilis : Charakterisierung verschiedener chromosomaler und phagenkodierter Systeme. $\mathrm{PhD}$ thesis, Freie Universität Berlin.

KISS, A. \& BalDaUf, F. (1983). Molecular cloning and expression in Escherichia coli of two modification methylase genes of Bacillus subtilis. Gene 21, 111119.

Maniatis, T., Fritsch, B. F. \& Sambrook, J. (1982). Molecular cloning : a laboratory manual. Cold Spring Harbor, NY: Cold Spring Harbor Laboratory.

Noyer-Weidner, M., PAWLeK, B., JeNTSCH, S., GüNTHERT, U. \& TRAutner, T. A. (1981). Restriction and modification in Bacillus subtilis: gene coding for a $B s u R$-specific modification methyltransferase in the temperate bacteriophage $\phi 3 T$. Journal of Virology 38, 1077-1080.

Noyer-Weidner, M., Jentsch, S., PaWlek, B., GÜNTHERT, U \& TrautneR, T. A. (1983). Restriction and modification in Bacillus subtilis: DNA methylation potential of the related bacteriophages $\mathrm{Z}, \mathrm{SPR}, \mathrm{SP} \beta, \phi 3 \mathrm{~T}$ and $\rho 11$. Journal of Virology 46 , 446-453.

NOYER-WEIDNER, M., JENTSCH, S., KUPSCH, J., BERGBaUer, M. \& Trautner, T. A. (1985). DNA methyltransferase genes of Bacillus subtilis phages: structural relatedness and gene expression. Gene 35 , 143-150.

Ratcliff, S. W., Luh, J., Ganesan, A. T., Behrens, B., Thomson, R., Montenegro, M. A., Morelli, G. \& Trautner, T. A. (1979). The genome of Bacillus subtilis phage SPP1: the arrangement of restriction endonuclease generated fragments. $\mathrm{Mol}$ ecular and General Genetics 168, 165-172.

Rigby, P. W. J., DieckmanN, M., Rhodes, C. \& Berg, P. (1977). Labelling deoxyribonucleic acid to high specific activity in vitro by nick translation with DNA polymerase I. Journal of Molecular Biology 113, 237-251.
Santos, M. A., Almeida, J., de lencastre, H., Morelli, G., Kamke, M. \& Trautner, T. A. (1986). Genomic organization of the related Bacillus subtilis phages SPP1, 41c, $\rho 15$, and SF6. Journal of Virology 60, 702-707.

Savva, D. \& Mandelstam, M. (1984). Cloning of the Bacillus subtilis spoIIA and spoVA loci in phage $\phi 105 \mathrm{DI}: 1 \mathrm{t}$. Journal of General Microbiology 130, 2137-2145.

Southern, E. M. (1975). Detection of specific sequences among DNA fragments separated by gel electrophoresis. Journal of Molecular Biology 98, 503-517.

TERSCHÜREN, P.-A. (1985). Untersuchungen zur Integration der Methyltransferase-Gene heterologer Phagen in das Genom des temperenten B. subtilis Phagen $Z$. Diploma thesis, Freie Universität Berlin.

Tran-Betcke, A., BeHrens, B., NoYer-Weidner, M. \& TRAUTNER, T. A. (1986). DNA methyltransferase genes of Bacillus subtilis phages: comparison of their nucleotide sequences. Gene 42, 89-96.

Trautner, T. A., Pawlek, B., Günthert, U., Canosi, U., Jentsch, S. \& Freund, M. (1980). Restriction and modification in Bacillus subtilis: identification of a gene in the temperate phage SP $\beta$ coding for a $B s u R$ specific modification methyltransferase. Molecular and General Genetics 180, 361-367.

Williams, M. T. \& Young, F. E. (1977). Temperate Bacillus subtilis phage $\phi 3 \mathrm{~T}$ : chromosomal attachment site and comparison with temperate bacteriophages $\phi 105$ and SP02. Journal of Virology 21, 522529.

ZAHLER, S. A. (1982). Specialized transduction in Bacillus subtilis. In The Molecular Biology of the Bacilli, vol. I, pp. 269-306. Edited by D. Dubnau. New York: Academic Press.

Zahler, S. A., Kormann, R. Z., Rosenthal, R. \& HeMPHILl, H. E. (1977). Bacillus subtilis bacteriophage SP $\beta$ : localization of the prophage attachment site, and specialized transduction. Journal of Bacteriology 129, 556-558. 